p-ISSN: 1412-1697; e-ISSN: 2477-3816

http://jurnal.radenfatah.ac.id/index.php/intizar

\title{
Analisis Kritikal Terhadap Penyaluran Dana Talangan Haji pada Bank Mega Syariah Cabang Pekanbaru
}

\author{
Ahmad Maulidizen \\ Department of Shariah and Economics \\ Universiti Malaya, Malaysia \\ Email: ahmadzen682@gmail.com
}

\begin{abstract}
Abstrak
Dana talangan haji merupakan pembiayaan dengan menggunakan akad qard atau ijārah yang diberikan kepada calon jamaah haji dalam upaya memperoleh nomor porsi haji atau Biaya Perjalanan Ibadah Haji (BPIH). Aplikasi produk ini memberikan kesan positif dan negatif, sehingga diperlukan ditinjau ulang mengenai keabsahan produk dan akibat yang ditimbulkan dalam pelaksanaannya. Hasil penelitian menunjukkan bahwa program ini memberikan dampak positif dan negatif, antaranya; (1) Nasabah dijamin bisa mendapatkan kursi haji dengan cepat, meskipun dari dana mereka tidak tidak mencukupi pembayaran biaya perjalanan haji, (2) Mencairkan dana secara mendesak bagi nasabah yang dananya masih belum bisa dicairkan dalam waktu cepat meskipun masih dalam bentuk deposito; (3) Proses pemberian dana talangan haji relatif cepat, sehingga keberangkatan ibadah haji dapat terencana dan tidak menunggu lama; (4) Fee atau ujrah (uang administrasi) yang diberikan relatif murah; (5) nasabah hanya membayar produk dari pinjaman; (6) Nasabah dapat mengansur setiap bulan atau bisa juga dibayar sekaligus sampai akhir pembayaran. Darii sisi negatif, ia bisa saja dianggap sebagai bagian dari fath al-dzari 'ah (membuka pintu bahaya) dan mendatangkan bahaya (mafsadah/ mudarat). Ditinjau dari Hukum Islam, keabsahan akadnya yang sangat riskan menjatuhkan kepada riba tersembunyi, karena dalam akad ini terjadi penggabungan antara akad al-qard dan al-ijārah dengan mensyaratkan adanya tambahan imbalan sebagai jasa, bahkan tambahan tersebut besarnya tergantung pada jumlah pinjaman dan lamanya masa pinjaman.
\end{abstract}

Kata Kunci: Analisis Kritikal, Dana Talangan Haji, Bank Mega Syariah

Haji merupakan salah satu ibadah pokok dalam Islam, dan bagi setiap muslim yang sudah mampu wajib melaksanakanya satu kali seumur hidup. Dalam istilah syara' haji adalah bentuk peribadatan menuju ke Baitullah dan tempat-tempat tertentu untuk melaksan, akan amalan-amanalan ibadah tertentu, yang dimaksud dengan tempat-tempat tertentu, selain Ka'bah dan Mas 'a (tempat sa $i$ ), juga Arafah, Muzdalifah, dan Mina, dan yang dimaksud dengan waktu tertentu ialah bulan-bulan

Intizar, Volume 23, Nomor 2, 2017 
haji yang dimulai dari Syawal sampai 10 hari pertama bulan Dzulhijah. Adapun amal ibadah tertentu ialah thawaf, sa'i, wukuf, mabit di Muzdalifah, melontar jumrah, mabit di Mina, dan lain-lain (al-Jazairi, 1999, hal. 44). Sebagai ritual yang penuh simbol perjalan seorang hamba menuju Allah SWT, dalam pelaksanaan ibadah haji berimplikasi luas terhadap kehidupan masyarakat muslim. Pelaksanaan ibadah haji bagi seorang muslim Indonesia tidak hanya sebagai tuntutang rukun Islam yang kelima (al-Bukhārī, 2003), tetapi sangat terkait dengan berbagai aspek sosial. Banyak segi kehidupan bermasyarakat yang terlibat dalam penyelengaraan ibadah haji, mulai dari persepsi masyarakat terhadap makna haji, nilai, dan normanorma yang terkandung di dalamnya, status orang yang telah berhaji, aspek ekonomi, hingga politik (Jazuni, 2005, hal. 409; Rosyada, 1999, hal. 15).

Konsekuensi logis dari semua itu, maka penyelenggaraan ibadah haji menuntut campur tangan dan tanggung jawab pemerintah secara serius dari pemerintah Saudi Arabia sebagai tuan rumah maupun pemerintah Indonesia sebagai tamu. Tuntutan itu semakin mendesak manakala minat jamaah haji dari berbagai negara terus bertambah secara signifikan dan bahkan melampaui batas kuota yang ditetapkan pemerintah Saudi Arabia. Permasalahan yang timbul sekarang adalah banyaknya minat masyarakat untuk menunaikan ibadah haji dan terbatasnya daya tampung di tanah suci Mekkah sehingga membatasi bagi jamaah untuk melaksanakan ibadah haji setiap tahunya. Adanya porsi tunggu bagi jamaah, maka jamaah berlomba-lomba dalam mendaftarkan diri sebagai jamaah haji karena keterlambatan pendaftaran, mengakibatkan jamaah antri terlalu lama. Namun itu bagi jamaah yang telah cukup dana untuk mengambil porsi yang telah ditetapkan pemerintah, sedangkan bagi jamaah yang dananya belum cukup ini merupakan suatu kendala bagi jamaah untuk mendaftarkan dirinya sebagai calon jamaah haji. Oleh sebab itu banyak Instansi keuangan termasuk bank yang menawarkan jasa untuk mendaftarkan jamaah untuk mengambil nomor porsi haji atau Biaya Perjalanan Ibadah Haji (BPIH) yang disebut dengan dana talangan haji.

Indonesia merupakan Negara berpenduduk muslim tersebar di dunia hamper $85 \%$ yang tersebar dari sabang sampai marauke, oleh karena itu merupakan salah satu modal utama alasan banyak bank-bank konvensional membuka unit usaha Syariah ataupun membuka bank Syariah yang terlepas dari induk usahanya. Selain itu bank-bank Syariah berlomba-lomba membuat berbagai macam produk pembiayaan diantaranya produk pembiayaan talangan haji. Produk pembiayaan ini menggunakan prinsip Qard wal Ijärah. Dana talangan haji merupakan pembiayaan dengan menggunakan akad qard atau ijārah yang diberikan kepada calon jamaah 
haji dalam upaya memperoleh nomor porsi haji atau Biaya Perjalanan Ibadah Haji (BPIH). Pihak bank sangat antusias untuk menerbitkan produk tersebut seperti Bank Muamalat Indonesia, Bank Syariah Mandiri (BSM), Bank Mega Syariah, Bank Rakyat Indonesia (BRI) Syariah, dan bank lainya. Hal ini disebabkan karena banyaknya minat masyarakat terhadap produk dana talangan haji. Sebagaimana data yang penulis peroleh pada Bank Mega Syariah Cabang Pekanbaru yaitu jumlah nasabahnya dari tahun 2010 mulai produk ini diluncurkan pada bank tersebut sampai awal tahun 2012 mengalami peningkatan yang signifikan. Tahun 2010 jumlah nasabahnya yaitu 21 nasabah, tahun 2011 berjumlah 624 nasabah, dan tahun 2012 (jumlah nasabah bulan Januari sampai Februari) berjumlah 207 nasabah (Handayani, Widodo, \& Maulana, 2012). Untuk lebih jelasnya dapat dilihat pada tabel berikut:

\section{Tabel 1}

Jumlah Nasabah Dana Talangan Haji Bank Mega Syariah Cabang Pekanbaru Tahun 2010-2012

\begin{tabular}{|c|c|c|}
\hline No & Tahun & Jumlah Nassabah \\
\hline 1 & 2010 & 21 \\
\hline 2 & 2011 & 624 \\
\hline 3 & 2012 & 207 \\
\hline
\end{tabular}

Karena peningkatannya yang signifikan dan banyak diminati masyarakat merupakan indikasi bahwa produk dana talangan haji Bank Mega Syariah Cabang Pekanbaru ini memberikan dampak positif bagi masyarakat atau nasabah dan perbankan. Sebab, keberadaan dana talangan haji merupakan alternatif yang cukup menarik untuk mengatasi masalah sulitnya berhaji, baik karena faktor pendanaan yang belum mencukupi maupun karena terbatasnya kuota haji yang tersedia untuk calon jamaah haji di Indonesia, khususnya calon jamaah haji Pekanbaru. Namun demikian, disisi lain adanya produk dana talangan haji tersebut ada unsur riba dalam prakteknya. Hal ini disebabkan karena aplikasi dana talangan haji mengharuskan calon jamaah haji membayar sejumlah uang lebih dari dana yang dipinjamkan sebagai imbalan jasa (fee / ujroh) yang disinyalir sebagai riba dibalik praktik utang piutang dan pinjam meminjam. 


\section{Metode Penelitian}

Penelitian ini termasuk dalam jenis penelitian lapangan (field research), dengan metode deskriptif, yaitu suatu metode dalam meneliti status kelompok manusia, suatu objek, suatu kondisi, suatu system pemikiran atau suatu kelas peristiwa pada masa sekarang. Dilakukan di Bank Mega Syariah Cabang Pekanbaru. Populasi berjumlah 852 orang, diambil 85 orang (10\%) sebagai sampel penelitian, dengan menggunakan teknik random sampling. Teknik pengumpulan data; survey, angket dan wawancara.

\section{Penyaluran Dana Talangan Haji pada Bank Mega Syariah Cabang Pekanbaru}

1. Produk Pembiayaan Dana Talangan Haji Pada Bank Mega Syariah Cabang Pekanbaru

Produk pembiayaan dana talangan haji pada Bank Mega Syariah Cabang Pekanbaru adalah pinjaman dana talangan dari bank kepada nasabah khusus menutupi kekurangan dana untuk memperoleh kursi (seat) haji dan pada saat pelunasan Biaya Perjalanan Ibadah Haji (BPIH). Untuk membayar Biaya Perjalanan Ibadah Haji (BPIH), calon jamaah haji harus menyediakan uang atau modal sebesar Rp. 25.000.000,- untuk bisa mendapatkan nomor kursi keberangkatan haji. Tetapi tidak banyak masyarakat (calon jemaah haji) yang dapat membayar, karena masih terkendala dana yang belum terkumpul dalam waktu dekat. Oleh sebab itulah lembaga keuangan diberi kesempatan untuk membantu pengurusan haji. Dalam hal ini Bank Mega Syariah Cabang Pekanbaru menyediakan dana talangan bagi masyarakat (calon jamaah haji) yang masih kekurangan dana. Dengan adanya talangan tersebut dapat membantu mempercepat masyarakat mendapatkan kursi (Handayani, Widodo, \& Maulana, 2012).

Besarnya nominal Biaya Perjalanan Ibadah Haji (BPIH) sesuai ketentuan Kementerian Agama bahwa selama 5 tahun terakhir dan sampai dengan bulan April 2012, besarnya nominal Biaya Perjalanan Ibadah Haji (BPIH) adalah Rp. 25.000.000,0 adapun Biaya Perjalanan Ibadah Haji (BPIH) tersebut dapat dilihat pada table berikut; 
Tabel 2

Jumlah Pembiayaan Biaya Perjalanan Ibadah Haji (BPIH) 2008-2012

\begin{tabular}{|c|c|c|}
\hline No & Tahun & Biaya Perjalanan Ibadah Haji (BPIH) \\
\hline 1 & 2008 & Rp. $20.000 .000,-$ \\
\hline 2 & 2009 & Rp. $20.000 .000,-$ \\
\hline 3 & 2010 & Rp. $20.000 .000,-$ \\
\hline 4 & 2011 & Rp. $20.000 .000,-$ \\
\hline 5 & 2012 & Rp. $25.000 .000,-$ \\
\hline
\end{tabular}

Bagi nasabah dana talangan haji, sebelumnya harus mempunyai atau membuka rekening "Tabungan Haji". Tabungan Haji merupakan jenis produk pendanaan bank, melalui tabungan haji nasabah bisa mendapatkan dana talangan haji Bank Mega Syariah Pekanbaru. Tabungan Haji merupakan simpanan dalam mata uang rupiah yang bertujuan membantu masyarakat muslim dalam merencanakan ibadah haji dan umrah. Tabungan ini dikelola berdasarkan prinsip muḍārabah muṭlaqah, penyetoran awal terbilang Rp. 500.000. Tabungan Haji dilakukan nasabah yang ingin menabung untuk tujuan pembayaran Biaya Perjalanan Ibadah Haji (BPIH), tetapi waktu nasabah bisa mendapatkan porsi haji tergantung dengan kemampuannya dalam menabung. Lain halnya dengan dana talangan haji yang sudah jelas nasabah dengan waktu cepat mendapat porsi haji (Handayani, Widodo, \& Maulana, 2012).

Batas pembayaran maksimal 1 tahun setelah pengajuan pembiayaan. Selama masa pembayaran, nasabah boleh mencicil atau langsung tunai, karena bank akan mengambil secara sekaligus pada saat akhir batas pembayaran melalui Tabungan Haji. Apabila nasabah tidak mampu membayar dari waktu yang sudah ditentukan, maka diberikan perpanjangan waktu untuk 1 tahun ke depan sampai sebelum keberangkatan ibadah haji dengan membayar biaya administrasi satu tahu mendatang (Handayani, Widodo, \& Maulana, 2012). Dalam pembiayaan ini bank bertindak sebagai penyalur yang membantu pengurusan pendaftaran haji. Selanjutnya untuk daftar sebagai calon jamaah haji adalah tanggung jawab penuh nasabah. Nasabah (calon jamaah haji) memberikan kuasa pada bank untuk mengurusi semua yang menjadi persyaratan untuk mendapatkan porsi. Setelah berkas-berkas dan kekurangan Biaya Perjalanan Ibadah Haji (BPIH) untuk mendapatkan posri sudah terpenuhi, maka nasabah bisa langsung daftar ke Kementerian Agama (Hasimin, 2012). 
2. Prosedur Permohonan dan Syarat Pembiayaan Dana Talangan Haji pada Bank Mega Syariah Cabang Pekanbaru

Untuk pengajuan talangan haji pada Bank Mega Syariah Cabang Pekanbaru nasabah harus melalui beberapa tahapan. Diantaranya (Handayani, Widodo, \& Maulana, 2012);

a. Tahap ke-1, Bank Mega Syariah Cabang Pekanbaru menerima permohonan pembiayaan dana talangan haji dari nasabah;

b. Tahap ke-2, bagian marketing menganalisa dengan mengacu pada Pedoman Pembiayaan Bank Mega Syariah Cabang Pekanbaru;

c. Tahap ke-3, pembukaan rekening Tabungan Haji Bank Mega Syariah Cabang Pekanbaru;

d. Tahap ke-4, meminta nasabah memenuhi saldo minimal Tabungan Haji Bank Mega Syariah Cabang Pekanbaru, self financing biaya pendaftaran haji sebagai dasar pengajuan talangan pendaftaran haji dan biaya-biaya yang dikenakan kepada nasabah;

e. Tahap ke-5, bagian marketing menyerahkan data calon jamaah haji kepada kepala cabang. Pada tahap ini data-data yang telah dianalisa oleh marketing diajukan kepada kepala cabang untuk mendapatkan persetujuan;

f. Tahap ke-6, bagian marketing membuat SP3, memo, dan akad setelah mendapat persetujuan, membuat surat permohonan pengajuan pembiayaan, memo dan akad, akan diserahkan kepada calon jamaah haji yang mengajukan talangan;

g. Tahap ke-7, bagian administrasi pembiayaan mengecek kelengkapan data calon jamaah haji;

h. Tahap ke-8, bagian administrasi pembiayaan menyerahkan data kepada Manager Operasional dan Kepala Cabang untuk dianalisa kembali dan mendapatkan persetujuan Kantor Cabang melakukan penandatanganan akad.

i. Tahap ke-9, bagian administrasi melakukan pencairan dana langsung ke rekening calon jamaah haji serta menginput Surat Pendaftaran Pergi Haji (SPPH) untuk mendapatkan porsi.

j. Tahap ke-10, MO melakukan monitoring pada dana talangan yang diajukan.

Sebelum melakukan permohonan dana talangan haji Bank Mega Syariah Cabang Pekanbaru, ada beberapa syarat yang harus dipenuhi oleh pemohon 
(Hasimin, 2012), mencakup; 1) Syarat Pemohon, pemohon pembiayaan dibatasi hanya nasabah yang telah memiliki Tabungan Haji Bank Mega Syariah Cabang Pekanbaru dan menyetorkan BPIH melalui bank dengan kiteria; (a) cakap hukum; (b) perorangan yang mempunyai pekerjaan tetap dan/atau yang menurut penilaian bank diyakini memiliki kemampuan mengembalikan dana talangan haji tepat pada waktunya, dan (c) bersedia memberikan jaminan sesuai ketentuan bank. Nisbah memberikan jaminan kepada bank sesuai surat akad. 2) Syarat Nasabah atau Pemohon Dana Talangan Haji, adapun syarat pemohon meliputi; Nasabah perorangan, melengkapi; (a) Fotokopi KTP pemohon; (b) Fotokopi KTP suami/istri pemohon (apabila telah menikah); (c) Fotokopi Kartu Keluarga dan Surat Nikah (bila sudah menikah). Surat Cerai (bila janda/duda), (d) Surat Pernyataan batal haji; (e) Surat permohonan pengunduran diri dari calon jamaah kepada Kantor Kementerian Agama setempat; (f) Surat kuasa pengurusan pembatalan haji; (g) menyediakan kekurangan dana pendaftaran haji yang menjadi beban nasabah pada rekening Tabungan Haji Bank Mega Syariah Cabang Pekanbaru atas nama nasabah/ calon jamaah haji; (h) Fotokopi Tabungan Haji Bank Mega Syariah Cabang Pekanbaru.

Sementara syarat kelompok Bimbingan Ibadah Haji (KBIH)/ Penyelenggara Ibadah Haji Khusus (PIHK), melengkapi; (a) Fotokopi Akta Pendirian/ Anggaran Dasar; (b) Fotokopi KTP pengurus/ pihak yang berwenang mengajukan permohonan pembiayaan sebagaimana diatur dalam Akte Pendirian/ Anggaran Dasar; (c) Fotokopi Surat Izin Operasional dari Departemen Agama; (d) NPWP (untuk pembiayaan limit di atas Rp. 50.000.000,-; (e) Daftar nama calon haji yang akan diajukan untuk memperoleh talangan pendaftaran haji; (f) menyediakan kekurangan dana pendaftaran haji yang menjadi beban seluruh calon haji di bawah tanggung jawab Kelompok Bimbingan Ibadah Haji (KBIH) dimaksud pada rekening Tabungan Haji Bank Mega Syariah Cabang Pekanbaru atas nama masingmasing calon haji yang diblokir oleh bank; (g) Fotokopi KTP calon jamaa haji yang akan diajukan untuk memperoleh talangan pendaftaran haji; (h) Fotokopi Tabungan Haji Bank Mega Syariah Cabang Pekanbaru calon jamaah haji yang akan diajukan untuk memperoleh dana talangan haji. Untuk permohonan pembiayaan dana talangan haji yang akan diajukan oleh Kelompok Bimbingan Ibadah Haji (KBIH)/ Penyelenggara Ibadah Haji Khusus (PIHK), selain surat permohonan dana talangan haji dari Kelompok Bimbingan Ibadah Haji (KBIH)/ Penyelenggara Ibadah Haji Khusus (PIHK), juga wajib dilampiri permohonan pembiayaan dan sudah 
menandatangani dokumen-dokumen yang melalui Kelompok Bimbingan Ibadah Haji (KBIH)/ Penyelenggara Ibadah Haji Khusus (PIHK).

Sebagai lembaga keuangan yang berusaha meningkatkan kualitas pelayanan tanpa merugikan kedua belah pihak antara bank dan nasabah, terlebih dahuu dipertimbangkan sebelum memberikan pembiayaan pada nasabah, dengan menggunakan 6 C'S, yaitu; (1) Character; Pembiayaan dana talangan haji Bank Mega Syariah Cabang Pekanbaru dikendalikan oleh bagian RO Haji/ Pembiayaan Dana Talangan Haji, mereka yang bertanggung jawab untuk memberikan permohonan dana talangan atas nasabah. Setelah pembiayaan ini ditangani oleh Customer Service, dari pihak marketing menganalisa data nasabah terkait dengan kehidupan pribadi atau latar belakang nasabah. Upaya-upaya yang menggambarkan nasabah, diantaranya; (a) meneliti riwayat calon nasabah; Dalam hal ini bagian marketing mempelajari riwayat hidup dari nasabah, karena sebelumnya pihak bank sudah memberikan formulir untuk pengajuan dana talangan haji, yang sudah diisi oleh nasabah terkait dengan keadaan nasabah mulai dari nama, alamat, status nasabah, pekerjaan, jabatan dll; (2) Cakap Hukum; Nasabah harus mengerti tetang hokum dalam hal ini nasabah minial harus mengerti tentang perkreditan yang akan dia lakukan; (3) Melakukan Wawancara; Dalam hal ini pihak Customer Service memperhatikan nilai-nilai yang ada pada nasabah, misalnya; tata cara nasabah berpenampilan, bertutur kata, serta menunjukkan keyakinan untuk melakukan pembayaran. Bagian Marketing/ AO bertugas menganalisa pekerjaan dari nasabah; (4) Capital/Modal; Bank harus mengetahui berapa jumlah modal atau dana yang bisa disediakan sendiri oleh nasabah. Dalam praktiknya; bank mengalisa kekayaan dari nasabah, bank bertugas dengan melihat slip gaji dari nasabah, dan aset yang bisa meyakinkan nasabah dalam membayar utang, aset ini bentuknya tidak harus berupa uang, tanah atau bisa dalam bentuk bangunan. Modal awal yang harus disediakan bagi nasabah dalam permohonan bermacam-macam, di antaranya; 10 juta, 15 juta dan 18 juta. Persyaratan ini bertujuan untuk memberikan kemudahan untuk memilih dana sesuai dengan kemampuan nasabah;

(5) Capacity/ Kemampuan; Analisa ini bertujuan untuk mengetahui kemampuan yang dimiliki nasabah dari segi pendapatan. Upaya-upaya untuk bisa mengetahui kemampuan nasabah baik dari perorangan maupun KBIH, melalui beberapa pendekatan, diantaranya; (a) Bank Mega Syariah Cabang Pekanbaru melakukan pendekatan dari segi financial, yaitu; menilai latar belakang nasabah dari segi keuangan dan apabila permohonan dari KBIH pihak bank menilai keadaan dari yayasan penyelenggara ibadah haji tersebut; (b) Pendekatan Yuridis, yaitu 
permohonan dari KBIH apakah Yayasan tersebut mempunyai kapasitas untuk mewakili lembaga untuk mengadakan perjanjian pembiayaan dana talangan haji Bank Mega Syariah Cabang Pekanbaru; (c) Manajerial, yaitu menilai kemampuan nasabah (perorangan/ Kelompok Bimbingan Ibadah Haji) mulai dari perencanaan awal sampai pencairan dana talangan; (6) Collateral; Bank Mega Syariah Cabang Pekanbaru, memberikan kewajiban bagi nasabah untuk dapat memberikan jaminan. Jenis dari agunan ini dari pihak Bank Mega Syariah Cabang Pekanbaru meminta nasabah untuk memberikan "Surat Pernyataan Pembatalan Keberangkatan Haji di atas materai". Dapat mempengaruhi kelancaran pembiayaan. Upaaya-upaya untuk mengantisipasi terjadinya risiko, diantaranya; (a) Pemasaran; permintaan untuk talangan haji, persaingan antar bank, keadaan pasar, keadaan nasabah terutama wilayah Kota Pekanbaru; (b) Teknik dalam menarik nasabah dengan berbagai fasilitas yang disediakan, misalnya memberikan 3 pilihan dana talangan, perpanjangan waktu. Adapun waktu untuk keberangkatannya adalah tergantung kuota yang berada di daerah masing-masing; (c) Peraturan Pemerintah; Dalam hal ini jenis pembiayaan ini sudah mendapatkan fatwa dari MUI, dengan menggunakan akad qard dan bisa juga menggunakan akad ijārah; (7) Contrains; Dalam hal ini Bank Mega Syariah Cabang Pekanbaru tidak akan memberikan talangan haji bagi nasabah yang kurang mampu dari segi modal, dan kurang meyakinkan untuk melakukan pembayaran. Untuk Kelompok Bimbingan Ibadah Haji (KBIH), yayasan tidak mempunyai nilailebih atau unggul di dalam pengurusan ibadah haji, yang memungkinkan pembiayaan mereka akan ditolak Bank Mega Syariah Cabang Pekanbaru. Dari keenam prinsip di atas yang paling perlu mendapatkan perhatian bagian RO Haji/ PDTH adalah character, apabila prinsip ini tidak terpenuhi, maka prinsip lainnya tidak berarti, atau dengan kata lain, permohonannya harus ditolak.

3. Akad Penyaluran Dana Talangan Haji pada Bank Mega Syariah Cabang Pekanbaru

Dalam melaksanakan program pembiayaan Dana Talangan Haji Bank Mega Syariah Cabang Pekanbaru menggunakan dua prinsip, yaitu sewa (ijärah) dan pelengkap (Qard). Ijärah, bank bertugas sebagai pihak yang memberikan jasa sewa (memberikan talangan) dengan mengambil upah jasa (fee/ujroh) dari biaya-biaya administrasi yang dilakukan oleh bank karena sudah membantu nasabah dalam memperoleh porsi atau kursi keberangkatan haji. Qard, disini pihak bank bertugas memberikan pinjaman kepada nasabah (Handayani, Widodo, \& Maulana, 2012). Dalam praktik akad Qard, bank tidak mengambil keuntungan sesuai dengan prinsip Syariah, bank hanya bertindak sebagai pemberi pinjaman dan nasabah hanya wajib 
mengembalikan pokok utang pada waktu tertentu yang telaah disepakati di masa yang akan dating. Keuntungan diperoleh dari praktik akad ijärah, yaitu dengan mengambil upah jasa dari biaya administrasi atau lebih dikenal dengan (fee/ujrah) dari setiap dana disediakan oleh bank. Biaya administrasi itu terbagi menjadi empat kategori, yaitu; (1) Biaya administrasi Rp. 500.000,- dan (2) Talangan Rp. 12.500.000,- fee ijārah yang harus dibayar Rp.2.500.000,-; (3) Talangan Rp. 15.000.000,- fee ijārah yang harus dibayar Rp. 2.500.000,- (4) Talangan Rp. 20.000.000 fee ijārah yang harus dibayar Rp. 2.500.000,- (Handayani, Widodo, \& Maulana, 2012).

Berdasarkan uraian tersebut, bahwa tidak banyak nasabah yang dapat membayar BPIH dari jumlah yang ditentukan Kementerian Agama, kendala mereka bisa pada dana yang masih belum smua terkumpul dalam waktu dekat, kekurangan dana tersebut berbeda-beda, oleh karena itu Bank Mega Syariah Cabang Pekanbaru menyediakan beberapa pilihan jumlah nominal bagi para nasabah yang ingin menggunakan jasa talangan haji Bank Mega Syariah Cabang Pekanbaru. Adapun fasilitas pembiayaan dana talangan haji Bank Mega Syariah Cabang Pekanbaru;

a. Pinjaman dalam bentuk rupiah;

b. Jangka waktu maksimum pembayaran 12 bulan atau 1 tahun dan pembayaran dapat diangsur setiap bulan atau sekaligus sebelum jatuh tempo

c. Nominal talangan haji dan fee ujrah yang harus dibayar

d. Jumlah nominal yang disediakan bagi nasabah menggunakan jasa talangan haji Bank Mega Syariah Cabang Pekanbaru adalah; (a) biaya administrasi Rp. 500.000,- dan (b) Talangan Rp. 12.500.000,- fee ijārah yang harus dibayar Rp.2.500.000,-; (c) Talangan Rp. 15.000.000,-fee ijārah yang harus dibayar Rp. 2.500.000,- (d) Talangan Rp. 20.000.000 fee ijārah yang harus dibayar Rp. 2.500.000,- (Handayani, Widodo, \& Maulana, 2012) 
Gambar 1

Dana Talangan Haji Bank Mega Syariah Cabang Pekanbaru

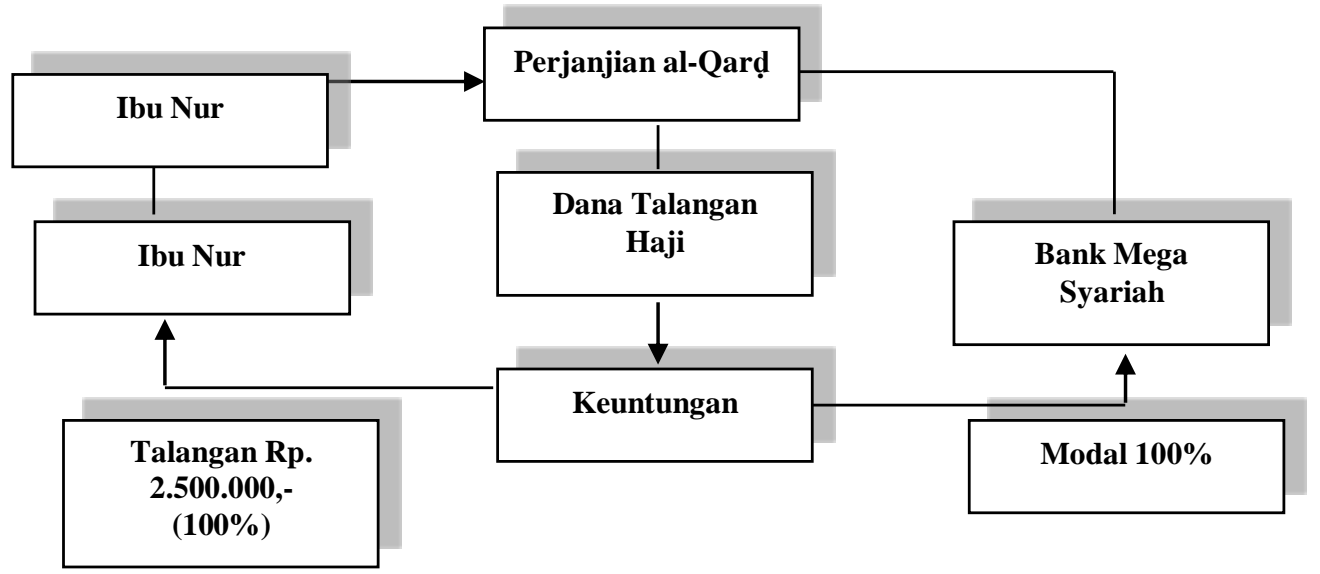

Berdasarkan gambar di atas menunjukkan bahwa pinjaman (keuntungan) yang diperoleh oleh ibu Nur Rp. 12.5000.000,- sedangkan Bank Mega Syariah Cabang Pekanbaru kembaali modal (pengembalian dana bank) Rp. 12.500.000,pengembaliannya sesuai pokok pinjaman tanpa bank harus mengambil keuntungan. Selanjutnya upah jasa dibebankan pada penggunaan akad ijārah. Dengan akad ijārah Bank Mega Syariah Cabang Pekanbaru bertugas sebagai pihak yang memberikan jasa sewa (memberikan talangan). Bank mengambil upah jasa dengan jumlah yang sama, dan nasabah hanya membayar upah jasa sesuai dengan jumlah yang telah ditetapkan oleh bank dan sesuai dengan kesepakatan pada saat akad dana talangan, baik dalam bentuk qirad maupun ijärah. Tindakan ini dilakukan untuk memberikan kemudahan bagi nasabah. Sebagai contoh berikut;

\section{Contoh A}

Permohonan pembiayaan

Pemohon

: Ibu Nur

Alamat

: Jl. KH. Ahmad Dahlan No. 7 Sukajadi Pekanbaru

Perihal

: Permohonan Dana Talangan Haji

Dana Talangan

: Rp. 12.500.000,-

Tanggal Pengajuan : 03 Mei 2011

Batas Pembayaran : 04 April 2012 
Biaya-biaya

Modal

Fee Ujrah

Tabungan Haji

Total Biaya
: Rp. 12.500.000,-

:Rp. 2.500.000,-

:Rp. 500.000,-

:Rp. 15.500.000,-

\section{Contoh B}

Permohonan pembiayaan

Pemohon

: Bapak Jufri

Alamat

: Jl. Melur No. 19 Padang Bulan Pekanbaru

Perihal

: Permohonan Dana Talangan Haji

Dana Talangan

: Rp. 15.000.000,-

Tanggal Pengajuan : 08 Agustus 2011

Batas Pembayaran : 06 Juli 2012

Biaya-biaya

Modal

: Rp. 10.000.000,-

Fee Ujrah

:Rp. 2.500.000,-

Tabungan Haji

:Rp. 500.000,-

Total Biaya

: Rp. 13.000.000,-

\section{Contoh C}

Permohonan pembiayaan

Pemohon

: Bapak Lukman

Alamat

: Jl. Markisa No. 19 Marpoyan Damai Pekanbaru

Perihal

: Permohonan Dana Talangan Haji

Dana Talangan

: Rp. 20.000.000,-

Tanggal Pengajuan : 08 Agustus 2011

Batas Pembayaran : 06 Juli 2012

Biaya-biaya

Modal

: Rp. 5.000.000,-

Fee Ujrah

:Rp. 2.500.000,-

Tabungan Haji

:Rp. 500.000,-

Total Biaya

: Rp. 8.000.000,-

Berdasarkan penjelasan sebelumnya, Bank Mega Syariah Cabang Pekanbaru membebankan upah jasa tidak ditentukan pada dana talangan yang diajukan. Dari 
ketiga contoh di atas, tidak ada perbedaan upah jasa yang harus ditanggung oleh pemohon. Upah jasa yang dibayarkan Ibu Nur lebih murah dibandingkan upaah jasa yang harus dibayar Pak Jufri dan Pak Lumkan, hal ini terjadi karena modal yang dimiliki lebih sedikit. Sehingga permohonan pembiayaan atau kekurangan dananya lebih besar dibandingkan dengan Ibu Nur. Dari ketiga permohonan di atas modal Pak Jufri yang paling sedikit dibandingkan dengan Pak Luman. Kondisi inilah yang membuat Pak Jufri menanggung upah jasa lebih besar.

Berdasarkan Fatwa Dewan Syariah Nasional No. 29/DSN-MUI/VI/2002, tentang pembiayaan pengurusan haji kepada nasabah, lembaga keuangan Syariah dapat memperoleh imbalan atau ujrah dengan menggunakan prinsip ijārah sesuai Fatwa Dewan Syariah Nasional No. 9/DSN-MUI.IV/2000. Sedangkan untuk pengambilan ujrah memutuskan bahwa, "Besar imbalan jasa ijārah tidak boleh didasarkan pada jumlah talangan al-Qard yang diberikan lembaga keuangan Syariah kepada nasabah (Indonesia, 2000). Pengambilan upah tersebut sebagai ganti biaya-biaya administrasi yang dikeluarkan bank, jadi meskipun jumlah talangan berbeda proses administrasi dari pemohon tersebut sama. Akan tetapi Bank Mega Syariah Cabang Pekanbaru juga memperhitungkan dengan melihat risiko pembiayaan yang diberikan pada nasabah semakin besar dana talangan, maka risiko bank semakin besar. Hal ini menunjukkan risiko pembiayaan Pak Jufri dan Pak Lumkan lebih besar daripada Ibu Nur.

\section{Dampak Dana Talangan Haji Pada Bank Mega Syariah Cabang Pekanbaru Terhadap Ekonomi Nasabah}

Pembiayaan Dana Talangan Haji Bank Mega Syariah Cabang Pekanbaru merupakan pinjaman dana talangan dari bank kepada nasabah khusus untuk menutupi kekurangan dana memperoleh kursi. Adapun manfaat lebih yang diberikan bank kepada nasabah dengan peluncuran program dana talangan haji Bank Mega Syariah Cabang Pekanbaru, antaranya; (1) nasabah dijamin bisa mendapatkan kursi haji dengan cepat, meskipun dari dana mereka tidak tidak mencukupi pembayaran biaya perjalanan haji, sehingga dapat daftar sebagai calon jamaah haji pada Kementerian Agama; (2) mencairkan dana secara mendesak bagi nasabah yang dananya masih belum bisa dicairkan dalam waktu cepat meskipun masih dalam bentuk deposito; (3) proses pemberian dana talangan haji relative cepat, sehingga keberangkatan ibadah haji dapat terencana dan tidak menunggu lama; (4) fee atau ujrah (uang administrasi) yang diberikan relative murah; (5) nasabah hanya membayar produk dari pinjaman, bukan hanya kemudahan ini yang 
diberikan Bank Mega Syariah Cabang Pekanbaru; (6) nasabah dapat mengansur setiap bulan atau bisa juga dibayar langsung atau sekaligus sampai akhir pembayaran (Handayani, Widodo, \& Maulana, 2012).

Dari penjelasan tersebut banyak manfaat yang diberikan Bank Mega Syariah Cabang Pekanbaru kepada nasabah yang ingin menunaikan ibadah haji, dimana nasabah bisa mendapatkan dana talangan haji meskipun modal mereka tidak sampai $50 \%$, dibuktikan dengan modal Rp 10.000.000 nasabah bisa mendapatkan kursi haji, bank akan menawarkan dana talangan maksimal Rp. 18.000.000,-. Hal ini merupakan keuntungan bagi nasabah yang masih mempunyai modal minim untuk pembayaran Biaya Perjaalanan Ibadah Haji (BPIH).

1. Kerelaan Nasabah Melakukan Akad Pembiayaan Dana Talangan Haji

Bagaimana kerelaan nasabah melakukan akad pembiayaan dana talangan haji pada Bank Mega Syariah Cabang Pekanbaru dapat ditelusuri pada table berikut;

Tabel 3

Kerelaan nasabah melakukan akad pembiayaan dana talangan haji

\begin{tabular}{llcc}
\hline No & \multicolumn{1}{c}{ Kategori } & Jumlah & Prosentase \\
\hline 1 & Rela dan sepenuh hati & 12 & $15,00 \%$ \\
2 & Rela & 68 & $85,00 \%$ \\
3 & Setengah hati & 0 & $00,00 \%$ \\
4 & Berat hati & 0 & $00,00 \%$ \\
5 & Terpaksa & 0 & $00,00 \%$ \\
\hline & Jumlah & 80 & $100 \%$ \\
\hline
\end{tabular}

Berdasarkan tabel diatas diperoleh informasi bahwa kerelaan nasabah melakukan akad pembiayaan dana talangan haji pada Bank Mega Syariah Cabang Pekanbaru, yang menyatakan rela dan sepenuh hati sebaanyak 12 orang $(15,00 \%)$ dan 68 orang $(85,00 \%)$ menyatakan rela. Ini menunjukkan bahwa produk pembiayaan dana talangan haji sangat diminati oleh nasabah terbukti dengan kerelaan hati para nasabah melakukan akad pembiayaan. Akad dilakukan dengan senang hati sehingga tidak perlu merasa berat hati untuk membayar angsurannya walaupun dengan adanya tambahan imbalan jasa (fee/ujrah) karena sudah ada kesepakatan di awal akad (Jufri, Nur'aini, Lukman, \& Zahara, 23 ).

2. Kemampuan Nasabah Membayar Ansuran Dana Talangan Haji

Bagaimana kesan nasabah terhadap produk dana talangan haji Bank Mega Syariah Cabang Pekanbaru, dapat diketahui melalui tabel berikut; 
Tabel 4

Kesan Nasabah terhadap Dana Talangan Haji

\begin{tabular}{llcc}
\hline No & \multicolumn{1}{c}{ Kategori } & Jumlah & Prosentase \\
\hline 1 & Sangat baik & 10 & $12,50 \%$ \\
2 & Baik & 40 & $50,00 \%$ \\
3 & Ragu-ragu & 20 & $25,00 \%$ \\
4 & Kurang baik & 10 & $12,50 \%$ \\
5 & Tidak baik & 0 & $00,00 \%$ \\
\hline & Jumlah & 80 & $100 \%$ \\
\hline
\end{tabular}

Tabel di atas menunjukkan bahwa produk dana talangan haji Bank Mega Syariah Cabang Pekanbaru cukup diminati oleh nasabah walaupun segala risiko yang ditanggung oleh nasabah, terbukti dengan kesan nasabah terhadap produk ini dengan pilihan jawaban responden terbanyak Nampak pada poin sangat baik dan baik sebanyak $62,50 \%$. Menurut nasabah mereka terkesan dan sangat bermanfaat, karena dengan produk dana talangan haji umat Islam dapat menunaikan ibadah rukun Islam ke lima dalam waktu dekat dan dapat diperoleh tanpa kesulitan, yaitu hanya membuka Tabungan Haji sebesar Rp. 500.000,- (Jufri, Nur'aini, Lukman, \& Zahara, 23 ).

\section{Kemampuan Nasabah Terhadap Produk Dana Talangan Haji}

Kemampuan nasabah membayar angsuran dana talangan haji pada Bank Mega Syariah Cabang Pekanbaru dapat diketahui pada tabel berikut;

\section{Tabel 5}

Kemampuan Nasabah Membayar Ansuran Dana Talangan Haji

\begin{tabular}{llcc}
\hline No & \multicolumn{1}{c}{ Kategori } & Jumlah & Prosentase \\
\hline 1 & Sangat Mampu & 20 & $25,00 \%$ \\
2 & Mampu & 30 & $37,50 \%$ \\
3 & Ragu-ragu & 20 & $25,00 \%$ \\
4 & Kurang mampu & 10 & $12,50 \%$ \\
5 & Tidak mampu & 0 & $00,00 \%$ \\
\hline & Jumlah & 80 & $100 \%$ \\
\hline
\end{tabular}

Pada tabel di atas, pilihan respondek terbanyak pada poin sangat mampu dan mampu sebanyak $62,50 \%$. Ini menunjukkan bahwa dampak produk dana talangan haji dinilai positif karena 50 orang responden memiliki kemampuan untuk 
membayar angsuran dana pembiayaan talangan haji yang telah digunakan, walaupun harus bersusah payah mendapatkannya (Mannan \& Khairiyah, 23).

\section{Ketepatan Waktu Nasabah Membayar Angsuran Dana Talangan Haji}

Nasabah membayar angsuran dana talangan haji Bank Mega Syariah Cabang Pekanbaru secara tepat waktu, dapat diketahui pada tabel berikut;

\section{Tabel 6}

Ketepatan Waktu Nasabah Membayar Angsuran Dana Talangan Haji

\begin{tabular}{llcc}
\hline No & \multicolumn{1}{c}{ Kategori } & Jumlah & Prosentase \\
\hline 1 & Selalu lebih awal & 20 & $25,00 \%$ \\
2 & Tepat waktu & 30 & $37,50 \%$ \\
3 & Sering menunggak & 20 & $25,00 \%$ \\
4 & Terkadang tertunggak & 10 & $12,50 \%$ \\
5 & Selalu tertunggak & 0 & $00,00 \%$ \\
\hline & Jumlah & 80 & $100 \%$ \\
\hline
\end{tabular}

Berdasarkan tabel di atas, pilihan jawaban responden terbanyak pada poin sangat tepat waktu dan tepat waktu sebanyak 62,50\%. Ini menunjukkan bahwa dampak produk dana talangan haji dinilai positif karena $62,50 \%$ reponden yang tepat waktu dalam melakukan pembayaran angsuran dana talangan haji (Irfan \& Nafsiah, 23).

5. Perasaan Nasabah Ketika Membayar Angsuran/ Melunasi Dana Talangan

\section{Haji}

Bagaimana perasaan nasabah ketika mambayar angsuran atau melunasi dana talangan haji pada Bank Mega Syariah Cabang Pekanbaru secara tepat waktu, dapat diketahui pada tabel berikut;

\section{Tabel 7}

Perasaan Nasabah Membayar Angsuran atau Melunasi Dana Talangan Haji

\begin{tabular}{llcc}
\hline No & \multicolumn{1}{c}{ Kategori } & Jumlah & Prosentase \\
\hline 1 & Puas dan senang hati & 15 & $18,75 \%$ \\
2 & Senang hati & 30 & $37,50 \%$ \\
3 & Ragu-ragu & 25 & $31,25 \%$ \\
4 & Kurang puas dan berat hati & 10 & $12,50 \%$ \\
5 & Terpaksa & 0 & $00,00 \%$ \\
\hline & Jumlah & 80 & $100 \%$ \\
\hline
\end{tabular}


Pada tabel di atas dapat dilihat bahwa jawaban responden pada poin puas dan senang hati sebanyak 56,25\%, ini artinya dampak produk pembiayaan dana talangan haji terhadap ekonomi nasabah dinilai negatif karena 45 orang responden merasa puas dan hati dan $43,75 \%$ yang merasa terpaksa dalam membayar angsuran atau melunasi dana datalangan haji yang telah digunakan. Mereka yang merasa puas dan senang hati disebabkan dana talangan haji dapat diperoleh tanpa kesulitan dan hanya membuka Tabungan Haji sebesar Rp. 500.000,- (Jufri, Nur'aini, Lukman, \& Zahara, 23 ).

\section{Kesimpulan}

Penyaluran dana talangan haji pada Bank Mega Syariah Cabang Pekanbaru menggunakan prinsip Qard wa al-Ijārah, penetapan upah jasa (fee/ujrah) dan penetapan pembayaran. Penyaluran dana talangan haji yang dijalankan Bank Mega Syariah Cabang Pekanbaru dalam aplikasinya, pihak bank mengmbil imbalan atau upah dengan jumlah yang sama, dan nasabah hanya membayar upah jasa sesuai dengan jumlah yang telah ditetapkan oleh bank dan sesuai dengan kesepakatan pada saat akad dana talangan haji. Tindakan ini dilakukan untuk memberikan kemudahan. Adapun manfaat bagi nasabah, antaranya; (1) nasabah dijamin bisa mendapatkan kursi haji dengan cepat, meskipun dari dana mereka tidak tidak mencukupi pembayaran biaya perjalanan haji; (2) mencairkan dana secara mendesak bagi nasabah yang dananya masih belum bisa dicairkan dalam waktu cepat meskipun masih dalam bentuk deposito; (3) proses pemberian dana talangan haji relatif cepat, sehingga keberangkatan ibadah haji dapat terencana dan tidak menunggu lama; (4) fee atau ujrah (uang administrasi) yang diberikan relatif murah; (5) nasabah hanya membayar produk dari pinjaman, bukan hanya kemudahan ini yang diberikan; (6) nasabah dapat mengansur setiap bulan atau bisa juga dibayar langsung atau sekaligus sampai akhir pembayaran. Namun demikian, di sisi negatif dari pembiayaan dana talangan haji Bank Mega Syariah Cabang Pekanbaru, ia bisa saja dianggap sebagai bagian dari fath al-dzari'ah (membuka pintu bahaya) dan mendatangkan bahaya (mafsadah/mudarat). Ditinjau dari Hukum Islam, keabsahan akadnya yang sangat riskan menjatuhkan kepada riba tersembunyi, karena dalam akad ini terjadi penggabungan antara akad al-qarḍ dan al-ijārah dengan mensyaratkan adanya tambahan imbalan sebagai jasa, bahkan tambahan tersebut besarnya tergantung pada jumlah pinjaman dan lamanya masa pinjaman. Dalam fiqh muamalah dikenal kaedah bahwa "Setiap piutang yang mendatangkan keuntungan atau lebih adalah riba". 


\section{Daftar Pustaka}

al-Bukhārī, A. '. (2003). Șaḥịh al-Bukhārī. Semarang: Maktabah Toha Putra.

al-Jazairi, ‘. a.-R. (1999). al-Fiqh 'Alā Mazahib al-Arba'ah. Meșir: Maktabah alTijāriyah.

Handayani, A., Widodo, \& Maulana. (2012, Agustus 20). RO Haji/ PDTH. (A. Maulidizen, Interviewer)

Hasimin, L. L. (2012, Desember 22). (A. Maulidizen, Interviewer)

Indonesia, M. U. (2000). Fatwa DSN-MUI No. 9/DSN-MUI/IV/2000. Jakarta: MUI. Irfan, M., \& Nafsiah. (23, Desember 2012). (A. Maulidizen, Interviewer) Jazuni. (2005). Legislasi Hukum Islam Di Indonesia. Jakarta : Citra Aditya Bhakti. Jufri, Nur'aini, Lukman, \& Zahara, S. (23 , Desember 2012). (A. Maulidizen, Interviewer)

Mannan, \& Khairiyah. (23, Desember 2012). (A. Maulidizen, Interviewer)

Rosyada, D. (1999). Hukum Islam Dan Pranata Sosial. Jakarta : PT. Raja Grafindo Persada. 